\title{
BYZANTINE NAVY DURING THE RULE OF THE FIRST PALAIOLOGAN EMPERORS (1259-1328)
}

\author{
Vladimir A. Zolotovskiy \\ Volgograd State University, Volgograd, Russian Federation
}

\begin{abstract}
Introduction. The purpose of this article is to reveal the military-strategic and economic grounds for the changes in the approaches to the formation and tactical designation of the early Palaiologan navy. The objectives are to determine the goals and methods of organizing the Byzantine naval forces in the context of the characteristics of the early Palaiologan priority campaigns.

The author reconstructs the military-strategic and economic grounds for the change in the approaches to the formation and tactical combat designation of the fleet of the early Palaiologan period.

Methods. The methodological basis of the work is the critical use of elements of civilizational, formational and systemic approaches. It should be noted that the system approach to the consideration of the military organization and navy as structural body allows to study their mutual influence, the role of the armed forces in society and the state, to reveal the causes and course of modernization in connection with society and state processes, to consider the functions and values (priorities) of individual elements of the military organization.

Analysis and Results. The analysis of changes in the organizational structure allows concluding that Genoese mercenaries had a special role in the fleet during the reign of Michael VIII. At the same time, the Byzantine navy was reinforced by a contingent of mercenaries of Roman origin who served on a long-term basis. The Andronicus II reorganized the fleet: instead of allocating funds for the re-equipment and manning of the Roman naval forces, the fleet was transferred to mercenary formations. From the tactical viewpoint, the Genoese and Venetian crews were used to solve specific tasks within one-time marine expeditions. This approach reduced the direct costs as only the specific operations of mercenaries were paid. At the same time, the protection of Constantinople was one of the priority functions of the naval forces.

Within the framework of the military operations of the Andronicus II's reign, the military fleet was used episodically to combat enhancement of the strategic protection of trade routes, as well as coastal territories provided by the existing fortification system. Despite the obvious military-material dependence, in a strategic sense, the use of naval forces based on mercenaries ensured defense of Byzantium's interests at sea, coastal security and protection of the islands from attacks by pirates, and timely transportation of land forces.
\end{abstract}

Key words: history of Byzantium, early Palaeologan period, military organization, Byzantine navy, mercenaries.

Citation. Zolotovskiy V.A. Byzantine Navy During the Rule of the First Palaiologan Emperors (1259-1328). Vestnik Volgogradskogo gosudarstvennogo universiteta. Seriya 4, Istoriya. Regionovedenie. Mezhdunarodnye otnosheniya [Science Journal of Volgograd State University. History. Area Studies. International Relations], 2018, vol. 23, no. 5, pp. 238-250. (in Russian). DOI: https://doi.org/10.15688/jvolsu4.2018.5.22

\section{ВИЗАНТИЙСКИЙ ФЛОТ ПЕРИОДА ПРАВЛЕНИЯ ПЕРВЫХ ПАЛЕОЛОГОВ (1259-1328)}

\author{
Владимир Алексеевич Золотовский \\ Волгоградский государственный университет, г. Волгоград, Российская Федерация
}

Аннотация. В рамках исследования раскрыты военно-стратегические и экономические основания произошедших изменений в подходах к формированию и тактическому боевому назначению флота раннепалеологовского периода. 
Осуществленный анализ изменений в организационной структуре позволяет сделать вывод о том, что в период правления Михаила VIII особая роль во флоте отводилась генуэзским наемникам. Правление Андроника II было ознаменовано реорганизацией флота.

С точки зрения тактического назначения генуэзские и венецианские команды использовались для решения конкретных задач в рамках разовых морских экспедиций. Такой подход позволил сократить прямые расходы казны, оплачивая лишь конкретные операции наемников. При этом охрана Константинополя была одной из приоритетных функций военно-морских сил.

В рамках военных действий периода правления Андроника II флот применялся эпизодически, для боевого усиления стратегической защиты торговых путей, а также прибрежных территорий, обеспеченных действующей фортификационной системой. Несмотря на очевидную военно-материальную зависимость, в стратегическом смысле применение военно-морских сил с основой на наемников обеспечило Византии защиту собственных интересов в море, безопасность побережья и охрану островов от нападений пиратов, своевременную транспортировку сухопутных формирований.

Ключевые слова: история Византии, раннепалеологовский период, военная организация, военно-морские силы, наемники.

Цитирование. Золотовский В. А. Византийский флот периода правления первых Палеологов (1259$1328)$ // Вестник Волгоградского государственного университета. Серия 4, История. Регионоведение. Международные отношения. - 2018. - Т. 23, № 5. - C. 238-250. - DOI: https://doi.org/10.15688/jvolsu4.2018.5.22

Введение. Возвращение Константинополя в 1261 г. знаменовало формальное начало новой эпохи в истории византийской военной организации. Фундамент новой военной машины был заложен в раннепалеологовский период, в период правления Михаила VIII и Андроника II.

Желание вернуть империи былое величие и прежние границы побудило Михаила VIII возродить боеспособность ромейских вооруженных сил. Однако если для организации крупномасштабных сухопутных кампаний было достаточно собственных сил и ресурсов, то противостояние многочисленным морским угрозам обнажило потребность в особом подходе к формированию флота.

Вопрос о специфике военно-морских сил Византии позднего периода неоднократно попадал в поле зрения исследователей. В частности, особое внимание уделялось выявлению специальной роли и смешанному составу корабельных команд, месту флотилий морских республик и средиземноморскому пиратству. При этом темы, упомянутые последними, представлены как в обобщающих работах, так и в специальных изысканиях. Несмотря на это, в науке был лишь затронут вопрос о сущности произошедших изменений в военно-морских силах Византии и их причинах. Цель данной статьи - раскрытие военно-стратегических и экономических оснований произошедших изменений в подходах к формированию и тактическому боевому предназначению флота раннепалеологовского периода. Задачи состоят в определении целей и методов организации военно-морских сил Византии в контексте характеристики ключевых кампаний периода правления Михаила VIII и Андроника II.

Методы. Методологической основой работы является критическое использование элементов цивилизационного, формационного и системного подходов. Отметим, что при анализе военной организации и флота как структурных совокупностей взаимосвязанных элементов системный подход позволяет изучить их взаимовлияние, роль вооруженных сил в обществе и государстве, раскрыть причины и ход модернизации в связи с общественными и государственными процессами, рассмотреть вопрос функций и значения (приоритетов) отдельных элементов военной организации. Системный подход также позволяет продуктивно изучить военную организацию во всей совокупности ее элементов, принципов развития и функционирования. Особое значение для исследования вооруженных сил и военного дела приобретает структурализм. Основные положения этого методологического подхода позволяют изучить ряд военных институтов и военно-научных концепций на предмет их специфики в раннепалеологовский период.

Анализ. Необходимость создания византийского флота после крушения империи в 1204 г. была очевидна, и организация флота относится еще к периоду правления Иоанна Ватаца. Об этом, в частности, свидетельству- 


\section{ВОЙНА И ОБЩЕСТВО В ВИЗАНТИИ. ИСТОРИЯ И ИСТОРИОГРАФИЯ}

ет Георгий Акрополит, сообщая о направлении никейской флотилии против Родоса в 1249 году [16, p. 398-11]. Однако наличие флота не могло обеспечить «империи в изгнании» победу в борьбе за Константинополь [5, p. 198199]. Очевидно, что, помимо явной потребности в тщательно разработанной стратегии кампании, предполагающей в том числе дипломатические мероприятия, это было результатом существенного отличия количества и качества венецианского и никейского флотов. Безусловно, в стремлении реализовать планы по восстановлению империи и возвращению столицы Михаил VIII нуждался в мощном, обученном и опытном флоте, способном быть конкурентом силам Венеции.

Единственным способным противостоять Венеции флотом располагала лишь Генуя. Именно в этот период, по мнению М.Н. Бахматовой, политические и экономические интересы Никейской империи и Генуи совпадали. В результате длительных переговоров, инициированных республикой 13 марта 1261 г., в Нимфее было заключено соглашение, согласно которому генуэзцы, получив коммерческие привилегии, были обязаны предоставить Михаилу VIII флот [25, p. 801].

После возвращения отвоеванного Константинополя Михаилу VIII предстояло организовать защиту города от возможных нападений венецианского флота. Как сообщает Никифор Григора, в связи с отсутствием собственного флота император стремился сохранить поддержку со стороны Генуи, зафиксированную в Нимфейском договоре [28, p. 9720-21]. Однако возможность измены Генуи под давлением латинян не позволяла Михаилу Палеологу безоговорочно рассчитывать на верность «союзников». В результате при сохранении формальной поддержки генуэзцев император приступил к формированию собственного флота и укреплению городских прибрежных стен. Особая роль военно-морских сил подчеркнута сообщением Пахимера, который указал, что «никогда невозможно было рассчитывать на удержание города ромеев (Константинополя. B. 3.) без абсолютного контроля над водами омывающих его морей»: «о

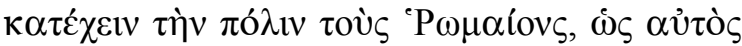

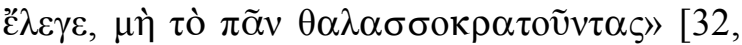
vol. II, p. $\left.403^{4-6}\right]$.
Поскольку первые морские кампании имперских военно-морских сил были организованы с 1263 г., можно предположить, что завершение строительства флота было возможно лишь в 1262 году [32, vol. I, p. 253 $3^{14-17}$, $271^{13-19} ; 28$, p. $98^{13-17}$ ].

Состав экипажей созданного флота был представлен выходцами из Мореи [32, vol. I, p. $\left.223^{4-7}, 253^{7}, 401^{23-28}-403^{1-3}\right]$. Основа флота состояла из лаконцев и гасмулов, бежавших с территорий, отошедших Византии по договоренности с Виллардуэном [35, p. 253-254]. При этом завербованные в Константинополь лаконцы вошли во флот как легковооруженные воины. Кроме того, они, подобно гасмулам, использовались как гребцы [32, vol. I, p. 253 $3^{5-12}$; 28 , p. $\left.98^{6-8}\right]$.

Укомплектовав таким образом флот, который, по данным Григоры, насчитывал более 60 кораблей [28, p. $\left.98^{7}\right]$, вероятно, Михаил Палеолог стремился усилить собственные вооруженные силы, способные сражаться истово в интересах империи. Очевидно, василевс старался реализовать идею Феодора II Ласкаря о создании «эллинской армии» [38, p. $58^{82-84}$. Эта цель в определенной мере была достигнута. За первые два года (1262-1263) морские силы Византии, сформированные преимущественно из «эллинов», смогли отвоевать «почти все острова» Эгеиды [32, vol. I, p. $151^{8-15}$. При этом, как указывает А. Файе, лишь только в 1270 г. у крепости Ореос состоялось морское сражение, в котором ромейский флот «впервые без поддержки наемников» нанес сокрушительное поражение латинскому флоту [10, p. 195-199].

В последующие годы определяющим фактором в наращивании военно-морской мощи империи были действия и намерения Карла Анжуйского. Новый сицилийский противник Византии не только пошатнул установившийся баланс сил в византийско-латинских отношениях, но и со всей очевидностью угрожал столице империи, а также всем ее морским владениям, составлявшим оборонительную линию на пути вражеского флота к Константинополю. В этой связи Михаил VIII предпринял все возможные меры, направленные на укрепление византийского флота, главной целью которых было установление союзнических отношений с Венецией и Генуей. 
Однако нежелание венецианского дожа ратифицировать договор 1265 г., а также, возможно, фактор заговора Гверчи [1, с. 15] подвигли Михаила Палеолога заключить соглашение только с Генуей [19, p. 146].

Одним из существенных условий соглашения было разрешение генуэзцам поселиться в Галате [25, p. 671]. Никифор Григора ошибочно располагает это событие сразу же после завоевания Константинополя в 1261 году $\left[28\right.$, p. $\left.97^{10-16}\right]$. В то же время, по сообщению Георгия Пахимера, мы знаем, что после освобождения Константинополя Михаил поселил генуэзцев вблизи Галаты [32, vol. I, p. 2276-8]. Безусловно, размещение в Галате прежде всего порождало в генуэзцах заинтересованность в обеспечении безопасности столицы. Империя же получала возможность контролировать генуэзцев, ввиду близости расположения, а также снизить вероятность участия генуэзцев в заговорах и конфликтах в Константинополе:

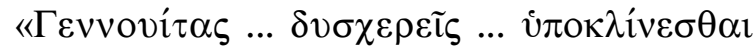

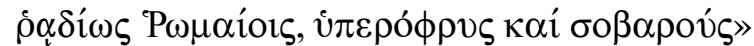

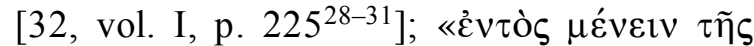

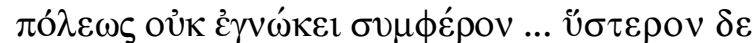

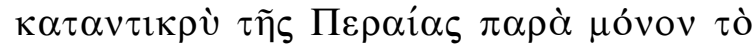

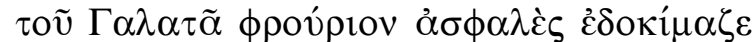

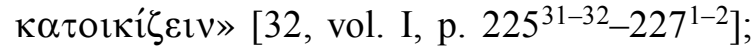

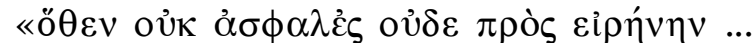

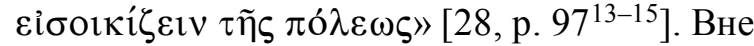
зависимости от ключевых факторов, подписанное соглашение знаменовало новый этап в византийско-генуэзских отношениях, длившийся, в различных степенях сближения, до 1453 года.

Кроме создания альянсов с морскими республиками, располагавшими сильным флотом, обороноспособность морских владений империи усиливалась посредством интеграции представителей нобилитета или же целых групп населения в военную организацию. Одним из наиболее ярких примеров использования таких инструментов в реализации оборонительной стратегической концепции империи было дарование Фокеи в пронию Мануилу Цаккарии [32, vol. II, p. 535 ${ }^{19-22}$; vol. IV, p. 60922-25; 19, p. 146; 33, № 6494]. По мнению Р. Лопец, Михаил Палеолог пожаловал в пронию Фокею Цаккарии для закрепления в Анатолии усиленной группировки, обеспечивавшей защиту островных владений империи в Эгеиде от напа- дений противника, а также охранявшей анатолийские земли Византии от возраставшей турецкой экспансии [24, p. 12-13].

Безусловно, следует признать обоснованным мнение Р. Лопец в вопросе конкретизации военной функции в качестве одной из функций пронии. Очевидно, именно в таких целях были жалованы пронии потомкам турок, пришедших в империю с Кайкавусом [3, c. 323-324].

Наиболее ярким примером такой практики, применительно к флоту, является случай с Иоанном Тарханиотом: направленный в восточные владения империи с целью организации управления делами императора архонт [32, vol. III, p. $\left.285^{21-22}\right]$ не только смог улучшить материальное положение пограничных «прониаров», но и построил немногочисленный флот [32, vol. III, p. 285 $\left.5^{31-33}\right]$. Возвращаясь к нашему сюжету, подчеркнем, что на момент дарования Фокеи в пронию турки не представляли угрозы целостности малоазийских владений империи [34, p. 166-167].

Так, Х. Иналчич выделяет три этапа турецкой экспансии в Европу. С учетом хронологических рамок, акцентируем внимание на первых двух:

1-й этап (охватывает период с начала $\mathrm{XIV}$ в. по 20-е гг. XIV в.) характеризуется разбойными вылазками, предпринимаемыми отрядами, сформированными из разрозненных бейликов;

2-й этап (20-30-е гг. XIV в.) связан с завоеваниями армиями Айядинов и Османов соседних территорий [18, p. 228].

Таким образом, упомянутый случай выражает политическое и экономическое содержание пронии в отношении восточного направления. Использование военных ресурсов семьи Цаккария известно по сообщению Пахимера в пассаже, посвященному описанию противоборства Византии туркам [32, vol. IV, p. $609^{13-25}$; 34, p. 168] (вероятно, воинам эмирата Ментеше в начале XIV в. [11, p. 90]. A. Файе, со ссылкой на Regesten, датирует это событие 1304 г. [32, vol. IV, p. 608, not. 5]).

Безусловно, император рассчитывал на то, что для защиты своей торговли от пиратов в Эгеиде Цаккарии необходимо было иметь сильный флот. Согласно Марино Санудо, за непродолжительное время флот Цакка- 


\section{ВОЙНА И ОБЩЕСТВО В ВИЗАНТИИ. ИСТОРИЯ И ИСТОРИОГРАФИЯ}

рии уничтожил более двух тысяч пиратов [19, p. 146]. При этом эффективность такой формы обеспечения безопасности как основного элемента системы обороны, создаваемой на данной территории, подтверждается тем, что прония Цаккарии была последним завоеванием турок в Малой Азии [24, p. 59].

Согласно сообщению Пахимера, в начале XIV в. в связи с эскалацией турецкой угрозы вновь возник вопрос об обеспечении безопасности Фокеи. В этой ситуации Цаккария получил от императора повторное предложение об организации флота за счет прониарского дохода, или же они могли передать эти средства Андронику II для найма военно-морских сил [32, vol. IV, p. 609 $\left.{ }^{13-22}\right]$. Здесь следует указать, что, очевидно, уже через год, в 1305 г., Цаккария захватил о. Хиос [23, p. 25].

Постоянное военное противоборство в Морее и на островах архипелага сохранялось, в том числе благодаря активности пиратов. Несмотря на явный дестабилизирующий эффект, приступив к реорганизации оборонительной системы империи, Михаил VIII воспользовался и этим, казалось бы, абсолютно инородным и бесконтрольным элементом. При этом некоторые из флибустьеров привлекались на военную службу в Византии. Обеспечивая таким образом контроль над пиратами, империя устанавливала бо́льшую стабильность в Эгейском море, снижая расходы на содержание собственного флота. Вместе с тем наши предположения не исключают возможности солидаризироваться с мнением П. Хараниса о том, что приобщение корсаров к военным действиям осложняло ситуацию с безопасностью в Эгеиде и для византийцев. Однако, безусловно, наибольшие жертвы и торговые потери от генуэзских пиратов и ромеев несли противники Византии - венецианцы [8, p. 133]. При этом, как отмечает О.Е. Колотова, главным фактором частых грабежей византийцами венецианских кораблей была привлекательность венецианских торговых кораблей [2, с. 310].

Наиболее действенными и в определенной степени традиционными инструментами управления пиратами было введение их предводителей в имперскую систему военно-политического управления посредством наделения титулов, в ряде случаев наполняемых дол- жностными командными полномочиями. В этой связи в качестве одного из наиболее показательных примеров следует упомянуть назначение генуэзца Джованни де ло Каво на должность мегадуки [19, p. 132]. Д. Джианакоплос предположил, что назначение де ло Каво было произведено в 1278 г. после смерти Филанфропина [15, p. 211]. Однако утверждение о смерти Филанфропина в 1278 г. представляется крайне сомнительным. Более обоснованной является дата смерти полководца, обозначенная в просопографическом лексиконе, 1273 г., самое позднее - августом 1274 года [33, № 29751]. Отметим, что генуэзец был достаточно известным капитаном. По данным О.Е. Колотовой, де ло Каво фигурирует в Judicum Venetorum in causis piraticis contra Graecos decisiones как один из наиболее часто упоминаемых пиратов, причинивших венецианцам значительный ущерб [2, с. 307].

Характеризуя боевую практику, следует отметить, что основным стратегическим приоритетом в действиях византийского флота было западное направление. Важнейшей задачей было обеспечение безопасности от усиливающейся экспансивной политики Карла Анжуйского. Однако избранная Михаилом VIII тактика активного сдерживания противника потеряла свою актуальность в результате морского сражения в Пелазгийском заливе у города Димитриады. Боевое столкновение произошло по инициативе латинян. По сообщению Пахимера, причиной этого сражения было поражение войск Иоанна Палеолога в Mopee [32, vol. II, p. 4296-10]. Однако сражение было выиграно ромейским флотом, усиленным сухопутной армией Иоанна Палеолога [32, vol. II, p. 431 4-8].

После поражения у Неопатр [32, vol. II, p. $\left.525^{11-13}\right]$, новую кампанию в 1276 г. возглавил Ликарио. Вышедшие под его командованием объединенные византийские и наемные отряды латинян [19, p. 122] после длительной осады с моря и суши захватили Каристос. Продвигаясь по Эвбее, войска Ликарио захватили еще ряд сильнейших крепостей. На следующем этапе кампании были завоеваны острова архипелага и прибрежные города. За короткий период времени флоту Ликарио удалось подчинить Хиос, Серифос, Астипалос, Санторин и Ферасия, Сталимене (о. Лемнос), 
Наксос, Скопелос, Скирос, Скэфос, Аморгос, Церико и Церикотто [15, p. 295-296; 19, p. 123 $124,127]$. Григора указал, что Ликарио захватил Лемнос, Хиос, Родос и практически всех латинян архипелага захватил в рабство («по-

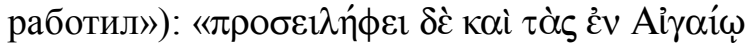

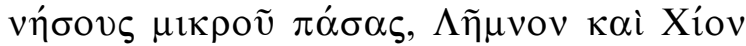

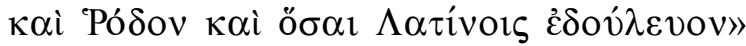
$\left[28\right.$, vol. 1, p. $\left.98^{15-17}\right]$. На заключительном этапе было организовано неудачное нападение на столицу Эвбеи.

Тем не менее за явные успехи Ликарио, прибывшего в Константинополь, вознаградили пожалованием титула великого коноставла [32, vol. II, p. 52722-26]. Согласно традиции, вскоре после этого (после смерти Филанфропина) Ликарио получил титул мегадуки - командующего византийским флотом [32, vol. II, p. $529^{4-7}$, vol. IV, p. $597^{6-7}$; 17, S. 212, 231].

Вернувшись из Константинополя, Ликарио вновь приступил к осаде столицы Эвбеи. При этом была полностью пересмотрена стратегическая концепция. Сосредоточив основные силы в замке Фила, до конца своей карьеры Ликарио не прекращал нападений на латинян и организовывал рейды к островам архипелага, а также принял участие в объединенной с ромейским флотом экспедиции к Афино-Фиванскому герцогству $[19$, р. 127]. Полагаем, что действия Ликарио определенно соответствуют стратегии рассеянных концентрических ударов. Вполне очевидно, что основной целью этой стратегии было нанесение врагу наибольшего материального, морального и военного урона, и, как следствие, подавление противника, захват стратегической инициативы и овладение вражеской территорией. Важнейшей задачей, ставившейся перед Ликарио, очевидно, было ослабление противника и отвлечение его основных сил от владений империи и столицы. Таким образом, история службы латинского наемника Ликарио является еще одним подтверждением результативности реорганизованных Михаилом VIII военно-морских сил, основой которых были профессиональные наемные воины. Однако Д. Джианакоплос выдвинул абсолютно противоположное суждение, что, на наш взгляд, не соответствует результатам военных действий собственно византийской армии и наемных отрядов, находившихся под командованием Ликарио [15, p. 298].
Изменение состава и структуры военноморских сил было предпринято Андроником II. Согласно Георгию Пахимеру, в 1285 г. по распоряжению императора был упразднен ромейский флот [32, vol. III, p. 81 $28-30-83^{1-19}$, vol. III, p. 81, not. 87]. Э. Арвейлер, пытаясь понять причины роспуска флота, приходит к выводу, что главной причиной его роспуска может быть только потеря малоазийских владений, обеспечивавших большую часть нужд византийского флота [4, p. 379]. Это, по мнению ученого, предопределило не только невозможность восстановления флота, но и последующую невостребованность в нем. По мнению М. Бартусиса, это была не ликвидация, а сокращение флота. Американский историк подчеркнул, что основные подразделения военно-морских сил не упразднялись, а лишь были переведены в особое состояние. Так, гасмулы и лаконцы, по его мнению, с этого периода были представлены исключительно эллинами [6, p. 68-69]. М. Бартусис предположил, что проселоны и гасмулы были лишены жалованья, получив в качестве вознаграждения за службу земельные участки [6, p. 68; 7, p. 12 19]. В этой связи следует заметить, что автор не только не указал правовой статус этих участков, но и не аргументировал вынесенные положения данными источников.

Основанием для этих выводов служит издание «Actes de Docheiariou» Н. Икономидиса [6, p. 70, not. 6]. Однако неясно, что именно послужило аргументом для столь спорных выводов, без каких-либо пояснений. В связи с упомянутой проблемой, выдвинутое историком предположение об этнической идентификации гасмулов также представляется необоснованным. По утвердившемуся в литературе мнению, они имели смешанное венецианско (итальянско)-византийское происхождение [20, p. 223; 21, p. 106-107]. При этом Д. Найкол, основываясь на специальном исследовании Ю. Хрисостомидиса, указал, что гасмулы пользовались в империи теми же правами, что и венецианцы [29, p. 199, not. 2]. Кроме того, на наш взгляд, данные источников позволяют более определенно раскрыть изменения, произошедшие в военно-морских силах Византии.

Полагаем, что упомянутое Георгием Пахимером событие было воспринято им в столь драматичной и категоричной форме, как 


\section{ВОЙНА И ОБЩЕСТВО В ВИЗАНТИИ. ИСТОРИЯ И ИСТОРИОГРАФИЯ}

ликвидация, ввиду его особых взглядов на причины поразивших империю военных провалов конца XIII - начала XIV века. Подтверждением этому служит приведенная историком публичная речь Афанасия I, в которой патриарх подчеркнул необходимость создания флота. Исходя из контекста сообщения Пахимера, потребность во флоте осознавали как император, так жители столицы [32, vol. IV, p. 581 $\left.{ }^{8-20}\right]$.

Возвращаясь к вопросу о сокращении численности флота, можно предположить, что наиболее очевидной причиной этого была естественная гибель кораблей, на восстановление или замену которых требовались значительные затраты. Наше предположение подтверждается словами Георгия Пахимера. Передавая василевсу предложение протовестиария Алексея Рауля и стратопедарха Синадина об упразднении флота, историк указал, что последующее содержание погибающих ромейских кораблей, которых к тому времени было до 80, «представляется приносящим больше вреда, нежели пользы» [32, vol. III, p. $81^{20-24}$ ]. Очевидно, что стремление всеми способами привлечь на службу наемные корабли морских республик было основано на желании снизить затраты на содержание собственных военно-морских сил. Показательным является преимущественное использование наемного флота при возникновении прямой угрозы столице. Несмотря на главенство наемных военно-морских сил и их очевидную значимость, византийский флот сохранился. Так, в нескольких пассажах Георгий Пахимер упоминает о действиях кораблей императорского флота [32, vol. IV, p. $\left.669^{8}, 695^{17}, 703^{7}\right]$. При этом лишь в одном из фрагментов историк указал, что под командованием Марулиса состояло до десяти кораблей «флота василевca» $\left[32\right.$, vol. IV, p. $\left.703^{7-8}\right]$.

Из-за неконкретности в высказываниях историка мы можем лишь предположить, что именно Пахимер понимал под императорским флотом. Очевиднее всего, императорскими были названы корабли генуэзцев, поскольку предводитель генуэзских наемников получал ромейский титул. Кроме того, к императорскому флоту могли быть отнесены корабли, построенные в конце 70-х - начале 80-х, еще до «ликвидации» флота. Возможно, физическое состояние позволило не уничтожить их ранее, а сохранить на службе в начале XIV века. Вероятно, именно об этих кораблях сообщает Георгий Пахимер в связи с венецианско-генуэзской войной $\left[32\right.$, vol. IV, p. $\left.355^{3-7}\right]$. Также, основываясь на том, что упоминания флота василевса встречаются в сочинении Пахимера в пассажах, посвященных событиям после произнесенной речи, можно предположить, что флот был создан по требованию жителей Константинополя в начале XIV века.

Кроме императорского и наемного флотов, безопасность поддерживалась силами прониаров. Мы уже упоминали о том, что в начале XIV в. Цаккарии, обратившемуся к императору с просьбой о помощи в защите Фокеи, Андроник II предложил либо передать доход от пронии в казну для найма флота, либо за эти средства самостоятельно нанять и содержать флот [32, vol. IV, p. 609 ${ }^{13-22}$. Цаккария выбрал наиболее выгодный для него последний способ [32, vol. IV, p. 609]. В этой связи считаем очевидным, что все прониары-попечители, чья власть распространялась на морскую или приморскую территории, были заинтересованы в обеспечении безопасности посредством найма флота.

Итак, можно предположить, что Андроник II провел реорганизацию флота в форме изменения способов его комплектования. То есть в конце XIII - начале XIV в. военно-политические и экономические факторы сделали возможным дифференциацию флота на две группы: столичную, нанимаемую и содержавшуюся на средства казны, и провинциальную, укомплектованную наемными судами и командами, поступавшими на службу прониарам или отдельным дукам за счет полученных ими прониарских доходов. В обоих случаях реорганизация флота происходила за счет использования сил наемников.

Как уже указывалось, корабли республики св. Георгия участвовали в особо важных экспедициях и кампаниях. В частности, генуэзский флот использовался василевсом в эпирской кампании 1292 года. Осознавая угрозу со стороны сил альянса, Карла Анжуйского и Иоанна Ангела, император направил к Янине многотысячные военные формирования пехоты и конных воинов [37, p. 570 $8791-8793]$. Кроме того, к Арте прибыл генуэзский флот из четырнадцати или шестнадцати генуэзских ко- 
раблей, перевозивших на бортах византийских воинов. Несмотря на многочисленность прибывших сил, укомплектованных турками и куманами, сухопутный контингент был разгромлен небольшим отрядом принца Ахайи Флорентом ле Хайнальто (Florent le Hainalt) $\left[37\right.$, p. 587-588 $\left.8^{9081-9087}\right]$. Д. Закифинос предположил, что принц Флорент был направлен Карлом II на помощь Никифору [39, p. 62]. О действиях флота Мореи ничего не известно. Сохранились лишь отдельные упоминания [22, p. 40-41; 30, p. 38-43; 31, p. 123]. После поражения армии флот отступил от Арты. Кампания была проиграна.

Отрицательное отношение современников к отказу от имперского флота и созданию столичных военно-морских сил, укомплектованных наемниками, очевидно, также могло быть вызвано пониманием явной связи безопасности столицы с действиями иностранцев. Так, например, во время блокады Константинополя кораблями республики св. Марка жители города испытывали все тяготы осады. Как очевидец, Пахимер, наряду с остальными жителями столицы, был разочарован мероприятиями Андроника II, приведшими к отсутствию собственных военно-морских сил, способных решать подобные конфликты незамедлительно [32, vol. IV, p. 355 $3-22]$.

Несколькими годами позднее в контексте новой угрозы морской осады, историк вновь сообщил о намерении Андроника II создать имперский флот. Речь идет о начале мятежа каталонцев [32, vol. IV, p. 581 $\left.{ }^{2-7}\right]$. В этой связи отметим, что само появление каталонского флота в Византии, вероятно, было связано с политическими интересами Арагона и Сицилии. Так, по сообщению Мунтанера, в период кризиса экспедиции сицилийский король Фридрих III под предлогом борьбы с «сарацинами» в Малой Азии отправил на восток инфанта Феррана [27, ch. CCXXX, p. 456-457].

По мнению Э. Мартин-Чабот, империя с начала кампании была объектом притязаний двух государств - Сицилии и Арагона. В начавшейся борьбе за империю сицилийский король сделал ставку на одного из каталонских лидеров, занявшего место предводителя наемников после смерти Рожера де Флора, Беренгария де Эстенцы [26, p. 199]. Надо отметить, что отправленный в Византию по предложению сицилийского короля Эстенца, был представителем одной из знатных семей Арагона. При этом Беренгарий сохранял вассальную преданность Хайме II Арагонскому, о чем свидетельствует текст письма Эстенцы, адресованного королю и датированного Э. Мартин-Чабот 20 июля 1304 года [26, p. 199 200, 201-203]. Кроме того, данные актовых материалов позволяют с определенностью указать, что Беренгарий де Эстенца с начала и до конца своей византийской миссии следовал курсу внешней политики дома Арагона, одной из целей которой был захват Романии [12, S. 678, № 428, 681, № 431].

Приведенное предположение подтверждается непреодолимым стремлением Хайме II любыми средствами вернуть Эстенцу из плена в Романию [9, p. 28-29]. Мнение о проарагонской направленности действий Эстенцы поддерживает Г. Шлемберже, объяснивший принятие Эстенцой помощи от Фридриха III как искусное дипломатичное использование проявившейся возможности всецело подчинить себе каталонцев и тем самым укрепить позиции Арагонского дома в империи [36, p. 168,172$]$.

Отметим, что, несмотря на организацию сухопутных походов, роль основной ударной силы империи на протяжении всего каталоновизантийского конфликта отводилась морским наемным силам. Очевидно, это было необходимо для оказания сопротивления мощному каталонскому флоту. Как сообщает Мунтанер, уже к началу экспедиции в империю каталонский флот насчитывал 18 галер и 2 корабля; «К тому же он (Рожер де Флор. - B. 3.) арендовал три больших корабля (nefs) и множество тарид (terides) и других кораблей (lins)»» [27, ch. CC, p. 416].

Учитывая мощь морских сил противника, по истечении несколько дней после убийства Рожера де Флора Андроник II договорился с генуэзцами о найме моряков и триер для нападения на каталонцев [32, vol. IV, p. 585 $30-32]$. Опираясь на сообщение Георгия Пахимера, можно предположить, что мятежные наемники стремились перенять инициативу в привлечении генуэзцев в совместные военные действия [32, vol. IV, p. 583 $27-31]$.

Генуэзцы, выступившие на стороне империи, несмотря на запугивания и предложе- 


\section{ВОЙНА И ОБЩЕСТВО В ВИЗАНТИИ. ИСТОРИЯ И ИСТОРИОГРАФИЯ}

ния, исходившие от каталонцев, в мае 1305 г. одержали решительную победу в морском сражении, захватив в плен Беренгария д’Эстенцу [32, vol. IV, p. 59122-27; 27, ch. CCXVII, p. 437]. Вместе с тем, опасаясь за жизнь соотечественников, генуэзцы отказались от участия в осаде Галлиполи [32, vol. IV, p. 595 $\left.{ }^{9-13}\right]$.

Кроме генуэзцев, военно-морскую поддержку империи оказывали венецианцы. Так, осенью 1305 г. пират венецианского происхождения Андре Мориско, получивший в качестве вознаграждения титул адмирала, поступил на службу со своим флотом [32, vol. IV, p. 607 $17-$ ${ }^{19}$ ]. К этому времени каталонцы под предводительством Феррана Хименеса приступили к длительной осаде Медитоса во Фракии [27, ch. CCXXIII, p. 445]. Осознавая возникшую для столицы угрозу, император приказал Мориско организовать экспедицию к Медитосу. В результате произошедшего столкновения $\left[32\right.$, vol. IV, p. $\left.643^{10-14}\right]$ поддержавшие каталонцев сицилийцы захватили адмирала Мориско в плен и продали его вместе с дядей в Тенедосе [32, vol. IV, p. 643 ${ }^{14-15}$ ].

Как сообщает Пахимер, в этих условиях, оценив возросшую угрозу от каталонского флота, усиленного сицийскими моряками, Андроник II вновь заключает с генуэзцами соглашение, рассчитывая на их помощь уже весной 1306 года [32, vol. IV, p. 595 $\left.5^{1-13}\right]$.

Важнейшим событием завершающего этапа морского противостоянии империи каталонцам был совместный поход генуэзсковенецианского флота к Галлиполи. К этой кампании империя смогла привлечь на службу четыре генуэзских военно-торговых судна [32, vol. IV, p. 661 $1^{4-6}$. Объединенный наемный флот в составе морских сил генуэзцев под командованием Спинолы и венецианцев во главе с Мориско был направлен к Галлиполи [32, vol. IV, p. 667 ${ }^{13-15} ; 27$, ch. CCXXVII, p. 451]. Малочисленным гарнизоном крепости командовал Рамон Мунтанер [27, ch. CCXXVI, p. 449].

Оценив свои силы, Мунтанер мобилизовал на защиту всех жителей крепости, включая женщин [27, ch. CCXXVII, p. 451]. При этом Мунтанер учел необходимость четкой организации питания, снабжения водой и своевременной замены уставших воинов новой сменой. Заманив главные силы осаждающих в засаду, малочисленный гарнизон одержал победу над наемным флотом [27, ch. CCXXVII, p. 453]. В последующем упоминании Пахимера о поражении военно-морских сил каталонцев в сражении на р. Марице летом 1307 г., скорее всего, проявляются положительные результаты реорганизации византийского флота. Командующим флотом, принявшим участие в этом сражении, назван грек Марулис [32, vol. IV, p. $703^{7-8}$ ].

В этой связи следует заметить, что состояние военно-морских сил при Андронике II было крайне неопределенным. После формального роспуска флота в 1284 г., по мнению Э. Арвейлер, отдельные уцелевшие корабли были возвращены в строй [4, p. 380]. Однако силы византийского флота были настолько неэффективными, что при повествовании о морских сражениях современники описывали действия наемных войск под руководством флотоводцев империи. Попытки изменить ситуацию привели к тому, что к концу правления Андроника II было изготовлено 20 кораблей $\left[28\right.$, p. $\left.524^{24}-525^{1}\right]$.

Результаты. Анализ изменений в организационной структуре, а также в стратегическом и тактическом назначении византийского флота в период правления первых Палеологов позволяет сделать следующие выводы.

Особая роль во флоте отводилась генуэзским наемникам. После возвращения Константинополя византийцы сохранили союзнические отношения с Генуей. В период правления Михаила VIII основным назначением генуэзских кораблей было участие в кампаниях, направленных на возвращение Пелопоннесских и Балканских земель, принадлежавших империи до IV крестового похода. Наемный флот использовался как для переброски сухопутной армии, так и для прямого участия в военных кампаниях. Корабли республики св. Георгия также сыграли важную роль в период обострения отношений империи с державой Карла Анжуйского и Венецией с середины 70-х до начала 80-х гг. XIII века.

Также следует отметить, что в период правления Михаила VIII военно-морские силы Византии усиливались контингентом наемников ромейского происхождения, служивших на долгосрочной основе. 
После смерти Карла Анжуйского у империи длительное время не было сильного морского соперника. В этой связи Андроник II предпринял реорганизацию флота: вместо выделения средств на переоснащение и доукомплектование ромейских военно-морских сил был осуществлен перевод флота на наемные формирования. С точки зрения тактического назначения генуэзские и венецианские команды использовались для решения конкретных задач в рамках разовых морских экспедиций. Такой подход позволил сократить прямые расходы государственной казны на содержание флота, затраты шли только на оплату конкретных операций военных наемников.

В рамках исследования было установлено, что в общей совокупности операций, в которых использовался флот, основная часть их была направлена на устранение угрозы безопасности столицы империи. Таким образом, можно сделать вывод о том, что охрана Константинополя была одной из приоритетных задач военно-морских сил.

Кроме того, в рамках военных действий флот применялся эпизодически, преимущественно для боевого усиления стратегической защиты торговых путей, а также прибрежных территорий, обеспеченных действующей фортификационной системой $[14 ; 13]$.

Таким образом, политика Андроника II в отношении военно-морских сил представляется достаточно обоснованной. Вполне очевидно, что к началу его правления, спустя почти четверть века после постройки флота его предшественником Михаилом VIII, практически иссяк военно-эксплуатационный ресурс кораблей. Поскольку столица Византии в этот период не испытывала реальной угрозы, не было необходимости в строительстве нового флота. К идее строительства флота, совмещенной с усилением военно-морских сил контингентом генуэзских наемников, Андроник II вернулся лишь в период обострения противоборства с мятежными каталонцами и усилившейся военной экспансии турецких бейликов, ряд из которых уже имел собственный флот, представлявший потенциальную угрозу Константинополю [34, p. 167-168].

Несмотря на очевидную военно-материальную зависимость империи, в стратегическом смысле применение военно-морских сил с наемной основой обеспечило Византии защиту собственных интересов в море, безопасность побережье и охрану островов от нападений пиратов, своевременную транспортировку сухопутных формирований. При этом даже появление такого сильного морского соперника, как каталонцы, получивших военно-морскую поддержку от Сицилии и Арагона, не побудило Андроника II построить полноценный по численности и боевому потенциалу ромейский флот. Император лишь пополнил существующие морские силы дополнительными кораблями.

\section{СПИСОК ЛИТЕРАТУРЫ}

1. Бахматова, М. Н. Взаимоотношения между Византией и итальянскими морскими республиками : автореф. дис. ... канд. ист. наук / Бахматова Марина Николаевна. - М., 2003. - 26 c.

2. Колотова, О. Е. Византийский флот и пиратство при императоре Михаиле VIII Палеологе (12611282 ) / О. Е. Колотова // Античная древность и средние века. - 2011. - Вып. 40. - С. 302-312.

3. Шукуров, Р. М. Тюрки в византийском мире (1204-1461) / Р. М. Шукуров. - М. : Изд-во Моск. ун-та, 2017. $-631 \mathrm{c}$.

4. Ahrweiler, H. Byzance et la mer, la marine de guerre, la politique et les institutions maritimes de Byzance aux VII $-\mathrm{XV}^{\mathrm{e}}$ siècles / H. Ahrweiler. - Paris : Pr. Univ. de France, 1966. - 506 p.

5. Angold, M. A. Byzantine government in exile : Government and society under the Laskarids of Nicaea, 1204-1261 / M. A. Angold. - L. : Oxford Univ. Press, 1975. - XX, $332 \mathrm{p}$.

6. Bartusis, M. C. The late Byzantine army : Arms and society, 1204-1453 / M. C. Bartusis. - Philadelphia : Univ. of Pennsylvania Press, 1992. - XVII, 438 p.

7. Bartusis, M. C. On the Problem of Smallholding Soldiers in Late Byzantium / M. C. Bartusis// Dumbarton Oaks Papers. - 1990. - Vol. 44. - P. 1-26.

8. Charanis, P. Piracy in the Aegean during the Reign of Michael VIII Palaeologus / P. Charanis // Charanis, P. Social, economic and political life in the Byzantine Empire / P. Charanis. - L. : Variorum Reprints, 1973. - P. 127-136.

9. En Garcia de Vergua i En Garcia Pérez d'Ayerbe, comissionats per la Companyía catalana, notifiquen a Jaume II que es dirigeixen a la presencia del Papa per a tractar dels fets d'En Berenquer d'Entença, de dita Companyía. Demanen son auxili a favor d'un i altre // Diplomatari de l'Orient Català (13011409). Collecció de documents per a la història de l'expedició catalana a Orient i dels ducats d'Atenes i 
Neopàtria / A. Rubió i Lluch. - Ed. facs. / Pròleg de M. T. Ferrer i Mallol. - Barcelona : Inst. d'Estudis Catalans, 2001. - P. 28-29.

10. Failler, A. Chronologie et composition dans l'histoire de Georges Pachymère / A. Failler // Revue des études byzantines. - 1981. - Vol. 39. - P. 145-249.

11. Failler, A. Les émirs turcs à la conquête de 1'Anatolie au début du 14e siècle / A. Failler // Revue des études byzantines. - 1994. - Vol. 52. - P. 69-112.

12. Finke, H. Acta aragonensia : Quellen zur deutschen, italienischen, französischen, spanischen, zur Kirchen und Kulturgeschichte: aus der diplomatischen Korrespondenz Jaymes 2, 1291-1327 / Herausgegeben von Dr. Heinrich Finke. - Berlin ; Leipzig : Walther Rothschild, 1908. - Bd. II. - S. 512-975.

13. Foss, C. Survey of medieval castles of Anatolia. Vol. II : Nicomedia / C. Foss. - L. : British Inst. of Archaeology at Ankara, 1996. - $112 \mathrm{p}$.

14. Foss, C. Byzantine fortifications / C. Foss, D. Winfield. - Pretoria : Univ. of South Africa, 1986. $298 \mathrm{p}$.

15. Geanakoplos, D. Emperor Michael Palaeologus and the West, 1258-1282 : A study in Byzantine-Latin relations / D. Geanakoplos. Cambridge (Mass.) : Harvard Univ. Press, 1959. - XII, $434 \mathrm{p}$.

16. Georges Acropolites. Historia // Georgii Acropolitae. Opera. In 2 vols. Vol. 1. Continens Historiam, Breviarium historiae, Theodori Scutariotae Additamenta / Rec. A. Heisenberg. - Lipsiae : in aedibus B. G. Teubneri, 1903. - P. 1-198.

17. Guilland, R. Études de titulature et de prosopographie Byzantines: les chefs de la marine byzantine / R. Guilland // Byzantinische Zeitschrift. 1951. - Bd. XLIV. - S. 212-240.

18. Inalcik, H. The Ottoman Turks and the Crusades, 1329-1522 / H. Inalcik // A History of the Crusades. Vol. VI/ Gen. edit. K.M. Setton.-Madison : Univ. of Wisconsin Press, 1989. - P. 222-275.

19. Istoria del regno di Romania sive Regno di Morea composta per Marin Sanudo / Marino Sanudo // Chroniques Gréco-Romanes / Inéd. ou peu connues publ. avec notes et tables généalogiques par C. Hopf. Berlin : Weidmann, 1873. - P. 99-170.

20. Jacoby, D. Les Vénitiens naturalisés dans 1'Empire byzantin: un aspect de l'expansion de Venise en Romanie du XIII au milieu du XV siècle / D. Jacoby // Studies on the Crusader States and on Venetian Expansion / D. Jacoby. - Northampton : Variorum Reprints, 1989. - P. 217-235.

21. Kyriakidis, S. Warfare in Late Byzantium, 1204-1453 / S. Kyriakidis. - Boston : Brill, 2011. - 272 p.

22. Laiou, A. Constantinople and the Latins : The foreign policy of Andronicus II, 1282-1328 / A. Laiou. Cambridge (Mass.) : Harvard Univ. Press, 1972. - XII, 390 p.
23. Laiou, A. E. Political history : An outline / A. Laiou // The economic history of Byzantium : From the seventh through the fifteenth century. In 3 vols. Vol. 1 / ed.-in-chiefA.E. Laiou. - Washington : Dumbarton Oaks Research Libr. and Collection, 2002. - P. 9-28.

24. Lopez, R. Genova marinara nel duecento : Benedetto Zaccaria, ammiraglio e mercante/ R. Lopez. Messina ; Milano : G. Principato, stampa, 1933. - XII, 290 p.

25. Manfroni, C. Le relazioni fra Genova l'Impero Bizantino e i Turchi / C. Manfroni // Atti della Società ligure di storia patria. - 1896. - T. XXVIII. - P. 651-809.

26. Martin-Chabot, E. L'expédition de la Compagnie catalane / E. Martin-Chabot // Le Moyen Âge : Bulletin mensuel d'histoire et de philologie. $2^{\mathrm{e}}$ sér. - Paris : Libr. Emile Bouillon, 1910., Vol. XXIII. P. 190-203.

27. Muntaner, Ramon. Chronica o descripcio dels fets e hazanyes dell inclyt rey Don Jaume Primer // Chroniques étrangères relatives aux expéditions françaises pendant le XIII ${ }^{\mathrm{e}}$ siècle / publ. pour la première fois, élucid. et trad. par J. A. C. Buchon. - Paris : A. Desrez, 1840. - P. 217-564.

28. Nicephorus Gregoras. Historia Romana. In 3 vols. Vol. 1 / ed. L. Schopen, I. Bekker. - Bonn : Weber, 1829. $-568 \mathrm{p}$.

29. Nicol, D. M. Byzantium and Venice : A study in diplomatic and cultural relations / D. M. Nicol. Cambridge ; N. Y. : Cambridge Univ. Press, 1988. - X, $465 \mathrm{p}$.

30. Nicol, D. M. The Despotate of Epiros, 12671479 : A contribution to the history of Greece in the Middle Ages / D. M. Nicol. - Cambridge ; N. Y. : Cambridge Univ. Press, 1984. - XIII, 297 p.

31. Nicol, D. M. The last centuries of Byzantium, 1261-1453 / D. M. Nicol. - L. : Hart-Davis, 1972. P. XII, 482.

32. Pachymérès, Georges. Relationes historiques /Éd. par. A. Failler, trad. par. V. Laurent. - Vol. I : Liv. IIII. - Paris : Les belles lettres, 1984. - 325 p. ; Vol. II : Liv. IV-VI. - Paris : Les belles lettres, 1984. - P. 328667 ; Vol. III : Liv. VII-IX. - Paris : Inst. fr. d'ét. byz., 1999. - 305 p. ; Vol. IV : Liv. X-XIII. - Paris : Inst. fr. d'ét. byz., 1999. - P. 306-727.

33. Prosopographisches Lexikon der Palaiologenzeit : CD-ROM Version / Hrsg. E. Trapp, R. Walther, H.-V. Beyer [et al.]. - Wien : Verl. d. Österr. Akad. d. Wiss., 2001. - 1 CD-ROM.

34. Pryor, J. H. Geography, technology and war. Studies in the maritime history of the Mediterranean, 649-1571 / J. H. Pryor. - N. Y. : Cambridge Univ. Press, 1988. $-208 \mathrm{p}$.

35. Raybaud, L.-P. Le gouvernement et l'administration centrale de l'Empire byzantin sous les premiers Paléologues (1258-1354) / L.-P. Raybaud. Paris : Sirey, 1968. -293 p. 
36. Schlumberger, G. Expédition des almugavares ou routiers catalans en Orient de l'an 1302 à l'an 1311 / G. Schlumberger. - Paris : Libr. Plon, 1902. - III, 396 p.

37. The Chronicle of Morea / introd., crit. notes and ind. by John Schmitt. - L. : Methuen and Co., 1904. $-640 \mathrm{p}$.

38. Theodori Ducae Lascaris. Epistulae CCXVII, Nunc primum / Ed. N. Festa. - Firenze : Tip. G. Carnesecchi e figli, 1898. - XII, 414 p.

39. Zakythinos, D. Le Despotat grec de Morée. 1262-1460. Vol. I : Histoire politique/ D. Zakythinos. Paris : Les Belles Lettres, 1932. - 336 p.

\section{REFERENCES}

1. Bakhmatova M.N. Vzaimootnosheniya mezhdu Vizantiey i italyanskimi morskimi respublikami: avtoref. ... dis. kand. ist. nauk [Relationship between Byzantium and the Italian Maritime Republics. Cand. hist. sci. abs. diss.]. Moscow, 2003. 26 p. (in Russian).

2. Kolotova O.E. Vizantiyskiy flot i piratstvo pri imperatore Mikhaile VIII Paleologe (1261-1282) [Byzantine Navy and Piracy under Emperor Michaels VIII Paleologus (1261-1282)]. Antichnaya drevnost $i$ srednie veka [Antiquity and the Middle Ages], 2011, vol. 40, pp. 302-312 (in Russian).

3. Shukurov R.M. Tyurki v vizantiyskom mire (1204-1461) [The Byzantine Turks, 1204-1461]. Moscow, Izd-vo Mosk. un-ta Publ., 2017. 631 p. (in Russian).

4. Ahrweiler H. Byzance et la mer, la marine de guerre, la politique et les institutions maritimes de Byzance aux $V I I^{e}-X V^{e}$ siècles. Paris, Pr. Univ. de France, 1966. 506 p.

5. Angold M.A. Byzantine government in exile: government and society under the Laskarids of Nicaea, 1204-1261. London, Oxford Univ. Press, 1975. $\mathrm{XX}, 332 \mathrm{p}$.

6. Bartusis M.C. The late Byzantine army: arms and society, 1204-1453. Philadelphia, Univ. of Pennsylvania Press, 1992. XVII, 438 p.

7. Bartusis M.C. On the Problem of Smallholding Soldiers in Late Byzantium. Dumbarton Oaks Papers, 1990, vol. 44, pp. 1-26.

8. Charanis P. Piracy in the Aegean during the Reign of Michael VIII Palaeologus. Charanis P., ed. Social, economic and political life in the Byzantine Empire. London, Variorum Reprints, 1973, pp. 127-136.

9. En Garcia de Vergua i En Garcia Pérez d'Ayerbe, comissionats per la Companyía catalana, notifiquen a Jaume II que es dirigeixen a la presencia del Papa per a tractar dels fets d'En Berenquer d'Entença, de dita Companyía. Demanen son auxili a favor d'un i altre. Rubió i Lluch A., Ferrer i Mallol M.T., eds. Diplomatari de l'Orient Català (1301-1409). Collecció de documents per a la història de l'expedició catalana a Orient i dels ducats d'Atenes i Neopàtria. Barcelona, Inst. d'Estudis Catalans, 2001, pp. 28-29.

10. Failler A. Chronologie et composition dans l'histoire de Georges Pachymère. Revue des études byzantines, 1981, vol. 39, pp. 145-249.

11. Failler A. Les émirs turcs à la conquête de l'Anatolie au début du 14e siècle. Revue des études byzantines, 1994, vol. 52, pp. 69-112.

12. Finke H., ed. Acta aragonensia: Quellen zur deutschen, italienischen, französischen, spanischen, zur Kirchen und Kulturgeschichte: aus der diplomatischen Korrespondenz Jaymes 2, 1291-1327. Berlin; Leipzig, W. Rothschild, 1908, vol. II, pp. 512975.

13. Foss C. Survey of medieval castles of Anatolia. Vol. II: Nicomedia. London, British Inst. of Archaeology at Ankara, 1996. 112 p.

14. Foss C., Winfield D. Byzantine fortifications. Pretoria, Univ. of South Africa, 1986. 298 p.

15. Geanakoplos D. Emperor Michael Palaeologus and the West, 1258-1282: a study in Byzantine-Latin relations. Cambridge (Mass.), Harvard Univ. Press, 1959. XII, 434 p.

16. Georges Acropolites. Historia. Heisenberg A., ed. Georgii Acropolitae. Opera. In 2 vols. Vol. 1: Continens Historiam, Breviarium historiae, Theodori Scutariotae Additamenta. Lipsiae, in aed. B.G. Teubneri, 1903, pp. 1-198.

17. Guilland R. Études de titulature et de prosopographie Byzantines: les chefs de la marine byzantine. Byzantinische Zeitschrift, 1951, vol. XLIV, pp. 212-240.

18. Inalcik H. The Ottoman Turks and the Crusades, 1329-1522. Setton K.M., ed. A History of the Crusades. Madison, Univ. of Wisconsin Pr., 1989, vol. VI, pp. 222-275.

19. Istoria del regno di Romania sive Regno di Morea composta per Marin Sanudo. Hopf C., ed. Chroniques Gréco-Romanes. Berlin, Weidmann, 1873, pp. 99-170.

20. Jacoby D. Les Vénitiens naturalisés dans l'Empire byzantin: un aspect de l'expansion de Venise en Romanie du XIII ${ }^{\mathrm{e}}$ au milieu du XV $\mathrm{X}^{\mathrm{e}}$ siècle. Jacoby D. Studies on the Crusader States and on Venetian Expansion. Northampton, Variorum Reprints, 1989, pp. 217-235.

21. Kyriakidis S. Warfare in Late Byzantium, 1204-1453. Boston, Brill, 2011.272 p.

22. Laiou A. Constantinople and the Latins: the foreign policy of Andronicus II, 1282-1328. Cambridge (Mass.), Harvard Univ. Press, 1972. XII, 390 p.

23. Laiou A.E. Political history: an outline. Laiou A.E., ed. The economic history of Byzantium: from the seventh through the fifteenth century. 


\section{ВОЙНА И ОБЩЕСТВО В ВИЗАНТИИ. ИСТОРИЯ И ИСТОРИОГРАФИЯ}

In 3 vols. Vol. 1. Washington, Dumbarton Oaks Research Libr. and Collection, 2002, pp. 9-28.

24. Lopez R. Genova marinara nel duecento: Benedetto Zaccaria, ammiraglio e mercante. Messina; Milano, G. Principato, stampa, 1933. XII, 290 p.

25. Manfroni C. Le relazioni fra Genova l'Impero bizantino e i Turchi. Atti della Società ligure di storia patria, 1896, vol. XXVIII, pp. 651-809.

26. Martin-Chabot E. L'expédition de la Compagnie catalane. Le Moyen Âge: Bulletin mensuel d'histoire et de philologie. Paris, Libr. Emile Bouillon, 1910, 2 ${ }^{\mathrm{e}}$ sér., Vol. XXIII, pp. 190-203.

27. Muntaner Ramon. Chronica, o descripcio dels fets e hazanyes dell inclyt rey Don Jaume Primer. Buchon J.A.C., ed. Chroniques étrangères relatives aux expéditions françaises pendant le XIII ${ }^{e}$ siècle. Paris, A. Desrez, 1840, pp. 217-564.

28. Schopen L., Bekker I., eds. Nicephorus Gregoras. Historia Romana. In 3 vols. Vol. 1. Bonn, Weber, $1829.568 \mathrm{p}$.

29. Nicol D.M. Byzantium and Venice: a study in diplomatic and cultural relations. Cambridge; N. Y., Camb. Univ. Press, 1988. X, 465 p.

30. Nicol D.M. The Despotate of Epiros, 12671479: a contribution to the history of Greece in the Middle Ages. Cambridge; N. Y., Camb. Univ. Press, 1984. XIII, $297 \mathrm{p}$.

31. Nicol D.M. The last centuries of Byzantium, 1261-1453. London, Hart-Davis, 1972, p. XII, 482.
32. Failler A., Laurent V., eds. Pachymérès Georges. Relationes historiques. Vol. I. Liv. I-III. Paris, Les belles lettres, 1984. 325 p.; Vol. II: Liv. IVVI, pp. 328-667. Paris, Les belles lettres, 1984; Vol. III: Liv. VII-IX. Paris, Inst. fr. d'ét. byz., 1999. 305 p.; Vol. IV: Liv. X-XIII. Paris, Inst. fr. d'ét. byz., 1999, pp. 306-727.

33. Trapp E., Walther R., Beyer H.-V. (et al.), eds. Prosopographisches Lexikon der Palaiologenzeit: $C D-R O M$ Version. Wien, Verl. d. Österr. Akad. d. Wiss., 2001. 1 CD-ROM.

34. Pryor J.H. Geography, technology and war. Studies in the maritime history of the Mediterranean, 649-1571. N. Y.,Cambridge Univ. Press, 1988. 208 p.

35. Raybaud L.-P. Le gouvernement et l'administration centrale de l'Empire byzantin sous les premiers Paléologues (1258-1354). Paris, Sirey, $1968.293 \mathrm{p}$.

36. Schlumberger G. Expédition des Almugavares ou Routiers catalans en Orient de l'an 1302 à l'an 1311. Paris, Libr. Plon, 1902. III, 396 p.

37. Schmitt J., ed. The Chronicle of Morea. London, Methuen and Co., 1904. 640 p.

38. Festa N., ed. Theodori Ducae Lascaris. Epistulae CCXVII, Nunc primum. Firenze, Tip. G. Carnesecchi e figli, 1898. XII, 414 p.

39. Zakythinos D. Le Despotat grec de Morée. 1262-1460. Vol. I: Histoire politique. Paris, Les Belles Lettres, $1932.336 \mathrm{p}$.

\section{Information about the Author}

Vladimir A. Zolotovskiy, Candidate of Sciences (History), Head of Department of Service and Tourism, Volgograd State University, Prosp. Universitetsky, 100, 400062 Volgograd, Russian Federation, zolotovskiy.azi@volsu.ru,https://orcid.org/0000-0002-4259-8851

\section{Информация об авторе}

Владимир Алексеевич Золотовский, кандидат исторических наук, заведующий кафедрой сервиса и туризма, Волгоградский государственный университет, просп. Университетский, 100, 400062 г. Волгоград, Российская Федерация, zolotovskiy.azi@volsu.ru, https://orcid.org/0000$0002-4259-8851$ 